\title{
Imigrantes da Bolívia na escola em São Paulo: fronteiras do direito à educação
}

\author{
Giovanna Modé Magalhães ${ }^{*}$, Flávia Schilling ${ }^{* *}$
}

Resumo: Entender como está sendo realizado o direito humano à educaçáo para os e as imigrantes da Bolívia que vivem em São Paulo é o principal objetivo deste estudo, que se insere no ponto de encontro entre dois debates globais contemporâneos: de um lado, os que envolvem a complexidade das migraçóes internacionais e, de outro, os que tratam das tensôes relativas à universalizaçâo de direitos em sociedades desiguais e discriminatórias. Ao longo da pesquisa, analisamos a legislação nacional e internacional e percorremos a literatura contemporânea sobre migraçóes internacionais e sua interface com o campo dos Direitos Humanos, em especial problematizando a relação entre os direitos de todos e os direitos dos cidadãos - dado que muitos que integram o grupo pesquisado vivem em situação irregular no Brasil, o que não lhes tira a garantia da realização de direitos fundamentais. Para uma melhor compreensão dessa dinâmica, visitamos locais de convivência dos imigrantes bolivianos(as) na cidade, realizamos encontros com representantes das organizaçóes que atuam com o tema e, finalmente, fizemos 16 entrevistas com estudantes, mães, pais, professores(as) e funcionários de escolas públicas da capital.

Palavras-chave: imigrantes; educação escolar; direitos humanos; preconceito.

\section{Immigrants from Bolivia at schools in São Paulo: borderlines for the right to education}

Abstract: The purpose of this study is to understand how the human right to education for immigrants from Bolivia in the city of Sao Paulo is being fulfilled. The research takes place at the crossroad between two contemporary global debates: on one hand, the growth and complexity of the international migration process and, on the other, tensions concerning rights universalization in unequal and discriminatory societies. Throughout this study, we analyzed domestic and international laws and discussed the literature on international migration and its interface with the field of Human Rights, particularly questioning the relationship between rights for citizens and rights for all - as many people from the group are living illegally in Brazil, what does not interfere in the entitlement of their fundamental rights. To capture the details of the relationships and characteristics around this process, we visited places in the city where Bolivian immigrants gather, we conducted exploratory

Mestre em Sociologia da Educação pela Faculdade de Educação da Universidade de São Paulo, Brasil.giovannamode@hotmail.com

** Professora da Faculdade de Educação da Universidade de São Paulo, Brasil. oak I @uol.com.br 
conversations with representatives from civil society organizations that fight for immigrants' rights, and, finally, we carried out 16 interviews with students, parents, teachers and employees from public schools in the city.

Key words: immigrants; education; human rights; discrimination.

\section{Introdução}

Nossa pesquisa ${ }^{1}$ teve como principal objetivo discutir como está sendo realizado o direito humano à educação escolar para os (as) imigrantes da Bolívia que vivem em São Paulo. Para tanto, dois debates globais contemporâneos estiveram presentes: de um lado, a crescente complexidade das migraçóes internacionais e, de outro, as tensóes relativas à universalização de direitos em sociedades desiguais e discriminatórias. Buscamos observar como acontece o acesso à educação escolar: como pensar a educação de pessoas desenraizadas, como lembra Martins (2001), numa das instituições mais territorializadas da modernidade?

São Paulo está entre as grandes cidades receptoras de imigrantes. Sua dinâmica continua atraindo não só brasileiros(as) de diversos outros estados, mas também estrangeiros(as), de uma maneira, no entanto, distinta das grandes migraçóes que caracterizaram o século XIX e a primeira metade do século XX. Com novos contornos e inserida em um contexto global bastante diferente, a metrópole tem como um dos notáveis fluxos de pessoas aquele originado nos países vizinhos latino-americanos. Dentre esses, o maior, segundo a nacionalidade, é o de bolivianos(as) ${ }^{2}$.

Trata-se de migração de pessoas que encontram trabalho em oficinas têxteis na cidade - estimadas entre 10 e 12 mil, concentradas, principalmente, na região central $^{3}$. São homens, mulheres, jovens, crianças, idosos, trabalhando em condiçóes penosas. O relatório de uma $\mathrm{CPI}^{4}$, em 2005, mostrou que, entre os problemas

I. Fronteiras do Direito Humano à educação: um estudo sobre os imigrantes bolivianos nas escolas públicas de São Paulo. São Paulo: Faculdade de Educação da Universidade de São Paulo, 2010.

2. A dimensão da população boliviana que vive no Brasil é uma incógnita. Os dados do Censo 2000 contabilizaram 20.015 bolivianos vivendo em território brasileiro. Já a Polícia Federal falava em 32.416 pessoas regularizadas. $\bigcirc$ Consulado da Bolívia fala em 50 mil indocumentados, enquanto para a Pastoral do Imigrante, o número está entre 70 e 80 mil. O Ministério do Trabalho e Emprego tem estimativas menores - entre 10 e 30 mil. O Ministério Público fala em 200 mil bolivianos ao todo (incluindo regulares e irregulares).

3. Os relatos das organizações da sociedade civil que trabalham com o tema são unânimes em mencionar que moram nos bairros onde está localizada a indústria da costura, a maioria na região central. No entanto, a pesquisa recente realizada por Cymbalista e Rolnik (2007) aponta para um fenômeno de desconcentração dessas oficinas, que poderia estar acontecendo por razões de segurança ou de busca de aluguéis mais baratos.

4 CPI instalada pela Câmara dos Vereadores do Município de São Paulo com o objetivo de "apurar a exploração do trabalho análogo ao de escravo nas empresas, regular ou irregularmente instaladas em São Paulo". Câmara Municipal de São Paulo, 2006. 
enfrentados, estáo: dificuldades de acesso aos serviços públicos, condiçóes de trabalho insalubres e intolerância da população residente em relação a hábitos, costumes e idiomas diferentes.

$\mathrm{Na}$ rede municipal de ensino paulistana, existem hoje 1.446 alunos e alunas nascidos na Bolívia (dados de 2009), além dos que estão matriculados na rede estadual $^{5}$ e dos que estão em idade escolar e fora de qualquer escola. Indagaremos, portanto, se e como os(as) imigrantes bolivianos(as) estão inseridos nos sistemas educativos, como constroem a relação com a comunidade escolar local, quais as características que têm marcado essa trajetória escolar e qual o sentido dessa passagem pela escola brasileira para eles e elas. Esse direito universalmente consagrado para todas as pessoas tem sido realizado nesse caso? Internacionalmente, observamos um crescimento dos estudos sobre as dinâmicas migratórias, especialmente nos países receptores de imigrantes, e um dentre os múltiplos enfoques trabalhados é a presença dos mais variados grupos de estrangeiros nos sistemas educativos locais. Essas pesquisas exploram questôes pedagógicas, como a preparação de professores para lidar com a diversidade, os desafios dos idiomas, a dificuldade de aprendizagem, entre outras. Há, ainda, as que tratam das relaçóes com as famílias, das diferenças culturais, da discriminação e do preconceito na escola. Verificamos a emergência do tema como um problema social, orientando uma série de investigações.

No Brasil, em um levantamento de pesquisas sobre as migraçóes internacionais e o direito à educação, encontramos poucos estudos acadêmicos. Essa constatação, talvez, retrate uma situação inversa à observada em outros lugares do mundo: a questão parece permanecer cercada de invisibilidade social e vista como sem importância, não despertando ainda grande interesse. Deparamo-nos, porém, com um crescente interesse pelo estudo da população boliviana em São Paulo, em especial no que diz respeito à dimensão do trabalho nas oficinas de costura ${ }^{6}$.

Além da pesquisa bibliográfica, do levantamento do tema na mídia impressa, da análise dos resultados da citada CPI e da análise da normativa nacional e internacional, realizamos visitas aos principais locais de sociabilidade dos bolivianos(as) em São Paulo. Visitamos espaços de convivência, como a Praça Kantuta, além de quadras de futebol e rádio comunitária, bem como percorremos instituiçôes - a maioria de caráter não governamental - que conformam uma rede de apoio aos e às imigrantes bolivianos(as) em São Paulo .

5. Número não disponível.

6. Destacamos, entre outras, a valiosa contribuição de Silva (1997, 2003, 2006 e 2007).

7. Entre elas, destacam-se a Pastoral do Imigrante, a Casa do Migrante, o Centro de Estudos Migratórios (CEM), o Centro de Apoio ao Migrante (CAMI) e o Serviço Pastoral do Migrante (SPM). Silva (2005) mapeou as principais associações e grupos de manifestações culturais em São Paulo. Cita a Associação dos Residentes Bolivianos (ADRB), responsável pela publicação do jornal mensal La Puerta del Sol. O Circulo Boliviano é fundado em 1975; em 200 I, surge a Associação comercial Brasil Bolívia(Bolbra), entre outras. 
Finalmente, fizemos as entrevistas com um diretor, uma assistente de direção, uma professora e dois professores numa escola municipal situada no bairro do Pari, e com mães e estudantes. Ao todo, participaram das entrevistas gravadas, de maneira individual ou coletiva, 16 pessoas. Numa entrevista-piloto, realizada com uma professora de uma escola municipal, foram relatados entraves das mais variadas naturezas (idioma, burocracia, documentação), dificuldades de diálogo, indícios de discriminação e um silêncio alarmante.

Desenhamos os três eixos analíticos que nortearam nosso trabalho de análise e apresentação das entrevistas. O primeiro deles foi o do acesso e da permanência na escola. Olhamos, especialmente, a questão da documentação exigida, bem como a relação com o idioma nativo. Está a educação plenamente disponível e acessível para a população imigrante boliviana?

No segundo eixo de análise, a proposta foi observar a relação entre os e as imigrantes bolivianos(as) e suas famílias com a comunidade escolar local e os pormenores do processo de diálogo e integração. Como, por exemplo, os filhos(as) de imigrantes nascidos no Brasil se viam frente à dupla cidadania formal? Brasileiros(as) ou bolivianos(as)? Aqui aparecem as questóes da diferença, da discriminação e da violência. A educação está aceitável e adaptável para esses estrangeiros?

Finalmente, o terceiro eixo de análise foi desenhado para conhecer as famílias de imigrantes bolivianos(as), incluindo os próprios alunos(as), mas não apenas: as mães mostraram-se interlocutoras privilegiadas. Quais eram suas expectativas, como viam a escola brasileira e qual o sentido dessa educação para os e as imigrantes?

\section{Imigrantes: contornos do debate}

Para a análise da situação dos imigrantes de origem boliviana nas escolas de São Paulo, três debates teóricos pareceram-nos necessários. O primeiro é o que envolve as dinâmicas migratórias contemporâneas. A Organização Internacional dos Migrantes das Naçóes Unidas ${ }^{8}$ mostrou que mais de 200 milhôes de pessoas vivem fora de seus países de origem. Sayad (1998) diz tratar-se de um "fato social completo", um fenômeno coletivo e individual que deve ser olhado a partir do cruzamento das ciências sociais com as contribuiçóes de diversas disciplinas, como história, geografia, demografia, economia, direito, psicologia, antropologia e política.

Ianni (2004), para referir-se às migraçôes contemporâneas, trabalha com o conceito de "transmigração", que engloba a heterogeneidade que marca a experiência migratória atualmente.

8. INTERNATIONAL ORGANIZATION FOR MIGRATION (IOM). World Migration 2008: Managing Labour Mobility in the Evolving Global Economy. Genebra. 
Aos que migram pela primeira vez, se somam os descendentes de migrantes, intensificando tensóes, crises e conflitos e ao mesmo tempo significados, vivências e horizontes, que vão impondo, ampliando e multiplicando as experiências de transculturação, pluralidade e relatividade nos países ocidentais (Ianni, 2004, p. 93)

Assim, uma segunda vertente conceitual que se faz necessária em nosso estudo são os debates recentes sobre as diferenças culturais e suas conexóes com uma sociedade desigual - dentro e fora dos sistemas educativos, já que, neste caso, os muros da escola são uma fronteira porosa. $\mathrm{O}$ imigrante traz consigo suas referências, sua religião, seu idioma, seus costumes e, em alguns casos, como o da população boliviana em São Paulo, traz também características étnicas. Ele é, em todo caso, um sujeito diferente. Há, assim, o reavivamento das diferenças, circunscrevendo a análise das tensões contemporâneas, como as levantadas por Touraine (1999), quando pergunta se, de fato, poderemos viver juntos.

Com o debate sobre as diferenças, Boaventura de Sousa Santos (2006) soma o fator da desigualdade, que nos parece ser uma dimensão fundamental para entendermos o lugar das discriminaçóes vividas pelas populaçóes migrantes, especialmente como o nosso grupo em análise ocupa a parte inferior da escala socioeconômica? .

Finalmente, a terceira vertente analítica na qual esta pesquisa se insere está nas disputas e tensóes em torno do campo dos Direitos Humanos. Dentre as várias possibilidades, dois eixos nortearam nosso estudo: a relação entre cidadania, direitos humanos e imigração, com especial ênfase nas contradiçóes entre os direitos de todos e os direitos dos cidadãos, e, por outro lado, a discussão sobre como se define o direito humano à educação.

Podemos afirmar que existe um consenso sobre a necessidade de garantir a esses não cidadáos a tutela necessária até que sua situação seja regularizada (Lafer, 1988). No entanto, esse tem sido um ponto clássico de tensão não somente na análise, mas também nas políticas contemporâneas. Como lidar com uma população que um determinado estado não quer receber - e que no limite já está em seu território? A segunda discussão no campo dos Direitos Humanos é justamente a que define como se dá a realização do direito à educação. Ainda que haja forte acordo internacional sobre a necessidade de uma "educação para todos", o entendimento sobre quem está neste "todos" e sobre como se realiza o direito à educação é também um campo de disputas.

9. Como ilustrou uma de nossas entrevistadas, M2, que veio de Potosí e estava em São Paulo há sete anos: Chegamos sem nada. Meu marido trabalhava numa empresa, mas foi jogado fora. Então a gente não tenia dinero, e meu marido não tenia trabalho na Bolívia, e você sabe que a mulher não deixam trabalhar. Meu filho mais caçula quando chegou tinha 8 anos. Quando eu cheguei aqui a gente procurava trabalho, e a gente não sabia costurar. Mas fomos trabalhar numa oficina de costura de um boliviano, um compatriota meu, que nos esclavizava, não fazia o pagamento. Agora já estou melhorando, moça, graças a Dios e graças a São Paulo.

Pro-Posições, Campinas, v. 23, n. 1 (67), p. 43-63, jan./abr. 2012 
Em sua Observação Geral nº 13 sobre o Direito à Educação, o Comitê de Direitos Econômicos, Sociais e Culturais (DESC) das Naçóes Unidas afirmou, em 1999, alguns critérios para a realização dos direitos educativos ${ }^{10}$, que se realiza quando a educação está disponível, acessível, aceitável e adaptável. Disponível no sentido de que haja instituiçóes e programas de ensino em quantidade suficiente; acessível, sem obstáculos econômicos, legais ou discriminatórios; aceitável, contando com padrôes mínimos de qualidade; e adaptável em relação à flexibilidade capaz de responder às necessidades dos estudantes, nos mais diferentes contextos sociais e culturais. Essa proposta ficou conhecida internacionalmente como o modelo dos " 4 As" (por sua sigla em inglês: available, accessible, acceptable, adaptable) e vem sendo utilizada como uma forma de verificar a realização desse direito.

Os imigrantes têm encontrado obstáculos em relação à acessibilidade (a documentação exigida é uma evidente barreira), à aceitabilidade (a discriminação), à adaptabilidade (diferenças ignoradas, a começar pela linguística). Os relatos mostrarão a opiniáo sobre a aceitabilidade (qualidade). A educação dos(as) bolivianos(as) imigrantes está, de fato, disponível, acessível, aceitável e adaptável?

Os direitos educativos voltaram a ser reafirmados nas normativas internacionais que tratam especificamente das populaçóes migrantes e dos refugiados. A Convenção Internacional sobre a Proteção de Todos os Trabalhadores Migrantes e Seus Familiares ${ }^{11}$ diz, em seu artigo 30, que o filho de um trabalhador migrante tem o direito fundamental de acesso à educação em condições de igualdade de tratamento com os nacionais do Estado receptor. No Brasil, a Constituição Federal de 1988 é certamente um marco para a educaçáo escolar, ao declarar toda a educação básica como direito subjetivo e exigível por qualquer pessoa nos sistemas de justiça. Em 1990, é aprovado o Estatuto da Criança e do Adolescente (ECA) ${ }^{12}$, que, em seu art. 53, garante "igualdade de condiçóes para o acesso e permanência na escola”.

Porém, o anacronismo do Estatuto do Estrangeiro (Lei 6815/80) já causou (e ainda causa, em alguns casos) entraves de diversas ordens para a realização dos direitos dessas populaçôes. Essa lei diz que as escolas só podem efetivar a matrícula, em qualquer grau de ensino, dos estrangeiros "devidamente registrados" (art. 48). Com base nessa premissa, em janeiro de 1990, foi aprovada a Resoluçáo n. 9 pela Secretaria de Educação do Estado de São Paulo, que proibia crianças sem documentos de frequentarem a escola, particular ou pública. O documento deliberava que os estabelecimentos de ensino deveriam exigir o Registro Nacional de

\footnotetext{
10. No $21^{\circ}$ período de sessões e acolhendo a sugestão da então relatora especial da ONU para o direito à educação, Katarina Tomasevski.

1।. O Brasil ainda não ratificou esta convenção.

12. Lei Federal N. 8.069 / 90
} 
Estrangeiro - RNE, fornecido pela Polícia Federal, e encaminhar a documentaçáo às Coordenadorias de Ensino ${ }^{13}$, que tinham a obrigação de entregar a relação dos estudantes à Secretaria de Educação, órgáo que, por sua vez, deveria enviar ofício com a informação ao Ministério da Justiça.

Antes dela, os(as) alunos(as) estrangeiros(as), inclusive aqueles(as) em situaçáo irregular, vinham normalmente frequentando a escola (Bonassi, 2000, p. 173). Estima-se que cerca de 400 crianças e adolescentes tenham deixado a escola naquelas circunstâncias no estado de São Paulo.

Diante daquele cenário, algumas organizaçóes da sociedade civil, entre elas a Comissão de Justiça e Paz e o Centro Pastoral dos Migrantes, pediram, formalmente, a revogação da Resolução N. 9. Juntos, elaboraram um dossiê $\hat{e}^{14}$ entregue, em fevereiro de 1994, ao Ministério Público.

No ano seguinte, no início de 1995, foi anulada a Resolução $\mathrm{N}^{\circ} 9$ e anunciada a $\mathrm{N}^{\circ} 10^{15}$, reforçando justamente o direito ao ensino para as crianças e para os adolescentes estrangeiros, independentemente do status legal em que se encontravam no país. Até hoje, são registrados entraves nesse sentido, ainda que a questão do acesso à escola, em todo caso, seja dada como resolvida.

No âmbito estadual, dois pareceres reafirmaram a Resolução, um em 1997 e outro em $2008^{16}$. O segundo, além de resolver a situação em questão, explicitou que "ao aluno estrangeiro deverá ser oferecido todo apoio pedagógico necessário para sua adaptação para que possa acompanhar os conteúdos curriculares da base nacional comum, especialmente no que se refere à aprendizagem da Língua Portuguesa" ${ }^{17}$. Em 2004, a população imigrante residente na cidade de São Paulo passou a contar com outro parecer, desta vez do Conselho Municipal de Educação. ${ }^{18}$

\section{Bolivianos(as) nas escolas}

Diante dessas questóes teóricas e do panorama normativo encontrado, empreendemos a pesquisa de campo. Como mencionamos anteriormente, o resultado das entrevistas foi organizado em três eixos analíticos: um primeiro, que tratou do acesso e da permanência na escola; um segundo, que abordou as relaçôes estabele-

13. Por meio das Delegacias de Ensino e das Divisões Regionais de Ensino.

14. Dossiê-Escola, Centro Pastoral dos Migrantes, 1994.

15. O advogado Belisário dos Santos Júnior, então Secretário de Justiça e Defesa da Cidadania, por intermédio da Comissão de Justiça e Paz, pediu a anulação da Resolução ao governador (Bonassi, 2000, p. 179).

16. Conselho Estadual de Educação, Deliberação 16, 1997; Conselho Estadual de Educação, nº 633/2008.

17. Na Bolívia, $74 \%$ da população é considerada indígena, a maioria de origem quechua (30\%) e aymará (25\%). No país são faladas 26 línguas e 127 dialetos (Silva, 2005).

18. Conselho Municipal de Educação, Parecer 17, 2004. 
cidas no ambiente escolar; e, finalmente, um terceiro, que tratou das expectativas das famílias bolivianas com relação à trajetória escolar.

\section{Documentos, idioma: as primeiras fronteiras do direito}

No primeiro eixo, perguntamos se e de que maneira se configura o direito à educação. A educaçáo está disponível e acessível para todos e todas? Uma primeira questâo é verificar possíveis barreiras no acesso à escola, no que diz respeito àqueles alunos(as) imigrantes em situação irregular no Brasil. A forma mais explícita de violação seria exigir uma documentação que essa população não possui e condicionar a ela tanto a matrícula como a emissão do certificado de conclusão de curso.

Ainda que os entraves ligados ao ingresso estejam longe daqueles narrados no início dos anos 1990 (Bonassi, 2000, p. 175), notamos que a matrícula não é um obstáculo inteiramente superado. Mesmo confirmando que a presença de bolivianos (as) aumentou nas escolas e que a informação sobre o direito à matrícula está mais disseminada, a questão não está resolvida. Explicitado na legislação - nos níveis internacional, nacional e local - e reafirmado nas resoluçóes dos conselhos estadual e municipal de educação, o entrave ganha um contorno de falta ou equivoco de informaçôes. Em nosso estudo, deparamo-nos com secretarias das unidades escolares que cobram um documento que essa população náo possui. Encontramos potenciais estudantes e famílias que não conseguem informaçôes sobre como continuar seus estudos. A principal impressão, neste caso, foi a de que as mães ou estudantes bolivianos(as) não costumam fazer uma segunda tentativa ou insistir em efetivar a matrícula: fato bastante esperado, dada a vulnerabilidade de pessoas que estâo sem documentação regular e, no limite, podem sofrer sançóes e deportação. Ao invés disso, a tendência é seguir primeiramente na batalha pela regularização no País, como ilustra o depoimento da mãe M2:

Meus filhos têm o problema que ainda não podem estudar, porque eles ainda não têm o documento. Nós estamos querendo renovar o documento, a permanência, mas eles falaram que nós temos que aguardar. [...] Agora meu outro filho queria também fazer estudo de motorista, e tampouco pode, por quê?? Porque não tem documento. ${ }^{19}$

$\mathrm{Na}$ entrevista de $\mathrm{E} 3$, jovem de 20 anos que tentou várias vezes matricular-se em cursos técnicos da rede pública e mesmo em cursos livres de computação da iniciativa privada, novamente ficam explícitas essas barreiras:

É muita burocracia [...]. O documento provisório não vale, eles querem o de permanência. Agora váo renovar de novo daqui a

19. Optamos por transcrever a fala dos depoentes como foram captadas, exatamente para revelar a questão crucial do idioma. 
180 dias. Renovam sempre, mas sempre ganhamos outro provisório. [...]. Os secretários das escolas não sabem como informar e não me deixam fazer os cursos.

O não conhecimento dos direitos fez-se notar também numa perspectiva mais ampla. A mãe M2 mencionou que "pediu um favor" para que o filho conseguisse a matrícula:

Meu segundo filho conseguiu estudar num instituto de computação, pedimos um favor para eles. [...]. O instituto era de um amigo meu boliviano, e como a gente é da Bolivia ele deixou. [...]. Mas nos institutos aqui de Brasil, la gente no quiere saber nada, no quiere. E também no ano passado falei com a directora aqui da escola, para que meu filho terminasse de estudar [...]. E então a diretora falou para mim: cadê documentos?, e eu falei para a diretora faz favor para mim, ele quiere estudar, eu disse faz favor para mim. Eu llorei, moça, para ela, lloré, então ela aceptó, graças a Dios aceptó moça.

Essa barreira apareceu explicitamente na fala do diretor que entrevistamos, que confirmou a dificuldade ao dizer que " $A$ mãe vem às vezes à escola e na secretaria exigem a certidão de nascimento, mas a gente sabe que pela legislação hoje náo precisa". Ele, entretanto, não apontou nenhuma medida no sentido de solucionar a questáo.

Entre mães, estudantes ou pessoas em busca de oportunidades educativas, ninguém conhecia a legislação e os direitos educativos da população migrante. Não houve referência a nenhum local onde pudessem encontrar esse tipo de orientação.

Outra questáo foi a da relação espanhol - português. Entre as pessoas com quem conversamos, nenhuma ingressou imediatamente na escola logo que chegou a São Paulo. Mesmo as que relatam uma trajetória escolar exitosa, contam que fizeram uma pausa - na maioria dos casos com duração de um ano - motivada pela insegurança com o novo idioma. A língua aparece como uma barreira inicial para todos(as) que imigraram. $\mathrm{Na}$ ausência de espaços de sociabilidade e convivência com brasileiros/as, a principal aliada para a aprendizagem do idioma, contam, é a televisão: "Eu parei de estudar um ano por causa da escrita, mas depois entrei na quinta série [...]. No começo, aprendi à base das músicas, minha máe comprava revistas e a televisão ajudou muito. Por isso não foi tão difícil." (E5, 17 anos). E4, menino que entrou numa turma de EJA aos 19 anos, confirma: "Está tudo bem, eu só tenho o problema da escritura [...] é só essa dificuldade no português mesmo [...]. A gente assiste muita televisão. A gente lê também. Mas às vezes a gente começa a falar algumas coisas que na hora que vai ver está errado". 
Exceto iniciativas pontuais de aulas de português para imigrantes adultos, não encontramos programas que visassem especificamente a um reforço aos alunos(as) que têm o espanhol como idioma nativo, ainda que a constatação da dificuldade com a língua escrita apareça claramente nas entrevistas com os professores:

Eles dominam na língua oral, porque a escrita é uma dificuldade. Tem coisas que são do espanhol. Então eles póem lá uma frase interrogativa e póem a interrogação ao contrário. Eu falo, olha, até tem sentido, mas no português não tem. Trocam as letras, o $B$ e o $V$. (P1)

No caso daqueles estudantes ou famílias que explicitamente querem retornar à Bolívia, há outro sentido: o objetivo seria de manter o espanhol, como lembra M3, mãe de dois meninos e duas meninas. Daí a decisão de mandar os filhos para estudar em seu país de origem: "É que eu não estoy de estar para siempre aqui, eu tenho que ir embora daqui unos quantos años, e é por isso que eu mandei allá, é um pouco complicado el idioma, perjudica, melhor que estudien allá."

É fato que, no âmbito privado, a grande maioria parece manter o idioma. Encontramos um caso de uma família, entretanto, residente em São Paulo há sete anos, em que a mãe pedia à filha $\mathrm{E} 5$, de 17 anos, que falasse apenas português em casa, pois, trabalhando na oficina de costura e permanecendo horas em casa, ela teria pouco tempo para aprendizagem do idioma: situação semelhante à relatada na passagem de Folclore e mudança social na cidade de São Paulo, em que Florestan Fernandes (1961) menciona a contribuição das crianças imigrantes de São Paulo no processo de socialização dos pais em meados do século XX.

Invisíveis, silenciosos: segunda fronteira do direito

O segundo eixo de análise diz respeito à relação entre bolivianos(as) e suas famílias com a comunidade escolar local - direção, professores e outros alunos(as) brasileiros(as). Destacaremos os relatos que evidenciam as tensôes no cotidiano, centradas na percepção da diferença, da discriminação, da violência.

Desde o início da pesquisa, os(as) bolivianos(as) eram descritos como estudantes silenciosos(as) e, muitas vezes, invisíveis dentro das escolas. Esse silêncio e essa invisibilidade pareciam comportar muitos sentidos e ambivalências que apareceram nas entrevistas.

São, assim, descritos como alunos que falam baixo, silenciosos, tímidos. Essa descrição era comum na fala dos professores. $\mathrm{O}$ diretor $\mathrm{D} 1$, por exemplo, não sabia o idioma que os alunos falavam entre eles: "nunca percebi, o que sei é que falam (espanhol) com a mãe; a mãe às vezes tem mais dificuldade de português". O professor P2 traz como uma primeira constataçáo a diferença que nota no comportamento 
das crianças: "Para nós eram diferentes por conta do comportamento que é diferente dos brasileiros. Os brasileiros são muito efusivos e os bolivianos mais retraidos, bastante mais retraídos".

Dentro da sala de aula essa característica se expressava de maneiras diversas, como relatou a professora P1.

Eu sei que eles têm dominio do português, mas eles têm medo de se expor. Então eles falam muito pouco, falam muito baixo, tem uns que nem respondem a chamada. [...]. E eles não perguntam. Eles não falam, então tem alunos que eu sei a voz porque eu vou lá e converso com ele, senão nunca escutaria. Vocêpergunta: "Você mora aqui na esquina?" ele responde: "-Não, não sei". Eles falam "não sei" para a maior parte das perguntas que você faz. (...) Dai eu fiz alguns seminários, mas ele não participava. Ele preferia ficar com "zero" do que falar.

Nas entrevistas com as mães e os(as) estudantes bolivianos(as), o silêncio e a timidez apareceram de duas formas: de um lado, como uma qualidade, uma forma de respeito ao ambiente escolar que traz consigo uma reverência à figura do professor. Por outro lado, a mesma característica foi relatada por outros(as) como um problema a ser superado: seria uma timidez responsável pela falta de defesa diante das agressóes verbais cotidianas que mais tarde vivenciaram. $\mathrm{O}$ primeiro significado, por exemplo, aparece na fala de E5, menina boliviana, de 17 anos, quando diz que:

Os professores elogiam muito nós, bolivianos, a gente ébem educado na sala, a gente não briga com professor, é porque a gente estuda, tiramos notas. Ai eles (os brasileiros) ouvindo isso falam "- ah, você é muito bonitinho, tem que fazer bagunça".

Alguns professores reconhecem que "a maioria é formada por alunos médios ou muito bons" e arriscaram uma interpretação, ainda que com dúvidas e desconfiança, como P3: "Acho que esse silêncio não deve ser só timidez, mas uma forma de reverência".

A mesma fala de E5 que comentamos acima, estudante do terceiro ano do Ensino Médio, trouxe a segunda forma de ver essa mesma característica, quando este relatou uma situaçáo em que teve de responder à provocaçáo de colegas que mexiam com ela e com outros amigos bolivianos: "Porque eles sấo tímidos sabe... tem uns certos meninos que mexem com você, mas se você não falar na hora eles vão continuar mexendo, isso que eu penso".

A mesma percepçáo emergiu enfaticamente na entrevista de M3, mãe, quando insistiu: 
Boliviano siempre es tímido, tiene miedo a falar, no fala nada, se calla [...]. É de menino que eu falava para eles [para os $f$ thos] que tem que saber defenderse, que tem que saber falar. Eu sempre ensino para eles que todos somos iguales. O que temos de diferente é o color, a profissão, mas somos iguales. Falo que no hay miedo. Só que as mães bolivianas não fazem isso. Não falam muito, fazem com que eles tenham medo, ficam na própria casa fechados, onde trabalha pai e mãe.

Esse traço, esse notável silêncio conduz-nos a outra reflexão, muito presente na conversa com professores, diretor e outras pessoas náo imigrantes de dentro e de fora da escola: diz respeito ao pouco conhecimento que se tem sobre a população de origem boliviana que vive em São Paulo. "Não conheço, não sei bem, acho que, parece, náo tenho certeza" foram expressóes que recorrentemente apareceram. Um exemplo é a entrevista da professora P1:

Em todas as classes, a gente tem pelo menos um. E em geral não fica em um, são dois, três... Chega a 10\% da classe. Logo que cheguei me impactou, falei: "como que tem uma comunidade dessa aqui? [...]. Achei que [os demais professores] conhecessem algo sobre eles, mas ai ao longo do tempo eu vi que não, eles me disseram que havia uma feira, mas na verdade a maior parte dos professores nunca nem foi nesta feira.

A professora P1 aponta um notável incômodo cada vez que tenta falar sobre o tema da imigração na sala de aula:

Ficam muito incomodados. [...]Eu não sei por quê[...]eu mesma conheço a Bolivia muito pouco, da questão dos bolivianos no Brasil também muito pouco. [...] Até tento, mas ai eu vejo que eles ficam tão incomodados. E ai um dia eu só chamei alguns: “ - Vocês querem que eu não fale disso?” e falaram: "-Não quero, quero que você não fale disso, fale de outras coisas".

Outra passagem interessante do relato desta mesma professora é sobre uma experiência com a turma de oitava série, em que tentou tratar da xenofobia e das migraçóes em outros países, já que muitos alunos(as) - brasileiros(as), neste caso - já expressaram de alguma maneira seu desejo de migrar.

Eles têm a idéia, têm o sonho de que eles vão para os Estados Unidos, e como imigrante vão chegar lá com lugar de destaque, vão ganhar a vida. [...]. Então eu pergunto: "-Você trata bem estrangeiro?" "- Não, mas comigo vai ser diferente porque eu vou me misturar". "- Não vai! Você acha que você tem a cara". E a gente fica nessa discussão. E na última aula em que tivemos 
essa discussão, tem uma boliviana na classe, e ela ria, ria.... E ela nunca se manifestou, ela normalmente fica quieta.

Uma fala que ilustra essas ambivalências é a de E5, de 17 anos. Conta que, quando chegou, sete anos atrás, não teve dificuldades para se integrar, era a única boliviana na sala de aula naquela época e foi bem recebida pelos colegas. Entretanto, comenta uma possível mudança nessa dinâmica nos dias de hoje:

Foi numa boa, recebi apoio de todos, porque eu era a única boliviana na sala, e um montão de brasileiros. Eles me olhavam assim e falavam "- nossa, vocêfala espanhol?" e vinham perguntar um monte de coisas da minha cultura. Perguntavam como era lá, como era a Bolivia. E eu dizia que era um lugar bonito, mas que era frio, e eles diziam "- ah, eu quero ir lá" [...]. Os professores foram legais também. Mas, sabe, do tempo de lá para cá mudou muita coisa. Agora tem, sim, um preconceito contra os bolivianos que chegam no Brasil.

Diante do desconhecimento, de um lado, e da discriminação, emergiam, não raro, indícios de um encontro - de certa maneira conflituoso - num dos únicos lugares onde a convivência entre imigrantes e nativos era certa, a escola.

Entre nossas perguntas iniciais, constava uma questão sobre como os filhos de imigrantes bolivianos, no caso os nascidos no Brasil, consideravam-se com relação à dupla nacionalidade. Havíamos percebido, na conversa com os professores, que passar a ser identificado como brasileiro era uma forma de resolver parte dos conflitos, eles entrariam numa zona mais segura, como contou P3: "Tem alguns que você pergunta: "- você é boliviano?”, e ele diz "- não, eu sou brasileiro, meu pai que é boliviano", como se tivesse algum problema. Como falavam os nordestinos antes".

Priorizavam o uso do português, em especial nos lugares públicos. No caso dos descendentes nascidos no Brasil, todos se definiam como brasileiros. M4, mãe de uma menina que nasceu no Brasil e hoje tem 12 anos, confirma:

Ela fala que não é boliviana, sempre fala que nasceu aqui. Ela não gosta que eu falo que ela é boliviana, eu não sei por que, pois desde pequena ela ficou com bolivianos. Uma vez falei para ela que era boliviana e ela disse que não, que quem nasce no Brasil é brasileira.

A existência de processos discriminatórios, presente em nossas hipóteses iniciais, não apenas se confirmou como ganhou contornos maiores do que prevíamos. Ainda que dificilmente aparecessem no início das entrevistas, cenas e relatos de discriminação e preconceito, em graus e dinâmicas variadas, marcaram todos os relatos de mães e estudantes, professores e pessoas de dentro e fora da escola. 
Mesmo que o tom geral da entrevista tentasse não realçar a existência de conflitos, situação exemplificada em falas como "está tudo bem, vivemos e estamos bem integrados aqui em São Paulo e na escola”, como foi o caso de E5, que pareceu estar satisfeita com a trajetória escolar e com as perspectivas futuras, o tema aparecia e, na grande maioria das vezes, com relatos de experiências pessoais. No caso desta estudante, isto surgiu quando ela narrou a dinâmica dos grupos de brasileiros e bolivianos:

São grupinhos, né, e de repente vem os brasileiros querendo saber: "o que vocês estão falando?". E nós dizemos "nada". Mas eles pensam que porque a gente está rindo, a gente está rindo deles, entendeu? Não tem nada a ver. Dai vem, às vezes briga, xinga... Dai um dia eu disse para eles a gente contribui para o seu pais.

O jovem E4, de 18 anos, que igualmente trouxe um discurso inicialmente marcado pelo "está tudo bem", sem se deter sobre os conflitos gerados por sua presença na turma de EJA de uma escola municipal, no final da entrevista revelou que não raro sofre discriminação: "Eu tenho um pouquinho de medo de errar o português e ser discriminado por isso, sim, porque tem pessoas lá no Brás que falam "ei estrangeiro o que tá fazendo aqui, devia ser deportado para a Bolivia”.

Na perspectiva dos professores, essa dinâmica é percebida e relatada como uma discriminaçáo que se manifesta claramente nas salas de aula. Como relata a professora P1, ou o diretor D1: "Na sala de aula as crianças diziam: "ah, o Bolivia ali professor". E eu dizia, "não, esse é o Cristian, ou o Vilmar etc..", para poder ir tirando isso. (D1)

Os argumentos são os recorrentes. Que eles não deveriam estar aqui, quando eles conseguem dinheiro para ir para outros lugares, ou voltar para a Bolivia ou Argentina, dizem: "Ai que bom que eles foram [...]". Por exemplo, estou lá explicando outra coisa que não tem a ver, e ele fala alguma coisa: "Olha, sai da frente ai seu boliviano, porque você devia voltar para a tua terra em vez de ficar me atrapalhando". E dai você não vê reação. (P1)

Outro professor é bem explícito:

Eles devem reproduzir o que os pais falam em casa. Parece que a relação no bairro é tensa, a relação do espaço, de como estão tomando nossos empregos. [...] Dizem: "ah, professor, eles sujam tudo, porque não voltam para o pais deles? Falam que os bolivianos não tomam banho, tem essa questão. E mantêm distância. [...] Às vezes me sinto despreparado também, não vou dizer que sei trabalhar com todas essas coisas que não é verdade, pois esta- 
mos falando de uma questão nova. É diferente, por exemplo, da questão do negro - pois eu sou negro, eu tenho uma bibliografia, já li muito até para me encontrar. Mas em relação à história da América espanhola, sou totalmente ignorante. (P3)

A jovem E6, que tem 19 anos e não frequenta a escola no Brasil, contou o caso de seu irmão, de 7 anos. Após sofrer situaçóes de violência e presenciar outras na escola onde estava, a mãe decidiu mandá-lo de volta para a Bolívia. O caso mais extremo que nos foi relatado foi sobre um garoto boliviano que foi agredido até morrer dentro da escola:

E6 - É que lá tinha muita discriminação. O menino trazia coisinhas assim balas, e os brasileiros tiravam dele, ai foi um dia que ele não quis dar. Acho que ele estava doente, que tinha alguma coisa no estômago, um tumor, não sei. E nesse dia eles bateram até machucar.

M3 - não foi uma vez, bateram várias vezes. Só que o menino falava para su mãe e su mãe tímida não falou nada, deixou o menino, não deu importância. [...] Ele (o seu filho) ficou muy traumado, tinha sete anos, e ele também apanhou. Então cuando murió el menino, acho que fizeram reunión com los padres, mas como a mãe era boliviana ela não fez nada, não falou nada. Eu não fui até lá, foi meu filho que me contou tudo.[...]. Muitos meninos bolivianos já não queriam mais ir à escola, meu filho falava "vão a bater em mi e eu vou morrer". Eu falava para ele que não, que não ia morrer, que tinha que saber defenderse. Eu fui com el, aí vino não sei se era directora ou algunas professoras, e falei para elas " $m i$ filho no quiere venir a la escuela, que acontece?". E ela disse: "aqui não aconteceu nada".

E6: Acho que foi um senhor lá na escola, não sei quem era, acho que do Ministério da Educação, falar que aquilo não podia, tanta discriminação, tinha muitos pais que estavam assim contra. Alguns diziam que os bolivianos tinham que ter uma escola à parte, mas esse senhor queria unir, que todos somos iguais, falava que tinha que ser a mesma escola, eu sei porque eu fui naquela reunião depois que morreu o menino. Tinha muita discriminação antes. Agora já não tem tanta.

\section{A escola brasileira no olhar boliviano}

Nosso terceiro eixo de análise é sobre as famílias e suas expectativas em relação à escola. O que a família imigrante boliviana espera da escola? O que dizem as mães sobre a relação com a escola, com os professores, sobre a permanência, o sucesso ou o fracasso escolar? 
Com base nisso, partimos para uma escuta atenta, em especial das mães com quem conversamos, e uma primeira característica que emerge é uma indignação, por parte delas, da dinâmica das escolas brasileiras. Aqui, os alunos não respeitam o professor, as mães não sabem educá-los para isso, não levam os estudos a sério:

Oproblema eram os meninos brasileiros que não têm educação, não respeitam a professora, não fazem tarea. Quando a professora toma la lección eles falam "eu não fiz". Como asi? Minha filha que já tinha estudiado na Bolivia ficava estranhada porque na Bolivia o estudio es estricto. Não pode contestar a uma professora assim! Aqui não, minha filha estava muy sorprendida, aqui não respeitam. Então a professora, porque no pode mais ter paciência, brigava e al dia seguinte já estava lá a mãe de ela dizendo "por que você gritou com minha filha?". Às vezes acho que os pais também estão errados. (M3)

A característica do respeito e de uma exigência maior com relação ao desempenho escolar aparece de outra maneira na fala dos professores. Em geral, enxergam as máes bolivianas como presentes e participativas, e suspeitam que vieram de uma cultura em que o desrespeito ao professor ou à instituiçấo escolar é inaceitável:

São bem presentes. [...] Ano passado dei um NS (Não Satisfatório) para um menino e ela veio me cobrar, querendo saber por que aquilo tinha acontecido. [...] Cobram autoridade, uma mãe boliviana uma vez me contou que de onde ela vinha o professor era permitido até a bater no aluno. (P2)

Os pais bolivianos não aceitam nota baixa. Noto também que essa atitude revela um caráter da própria cultura local. Parece que se tem certa reverência com o professor que não se tem aqui. E os filhos reproduzem. (P3)

Um elemento que apareceu na fala de uma das mães entrevistadas foi o sonho de que existisse uma escola separada". Pela descrição dela, referia-se a uma escola nos moldes das instituiçóes privadas que primam pelo atendimento específico a algumas nacionalidades:

Sabe, as veces yo quisiera una escuela a parte, sólo para los bolivianos, pero usted sabe, boliviano no es unido. Em La Paz, hay escuela de brasileiros, de alemanes, de americanos. Então as vezes acho que seria bom uma escuela para bolivianos, assim no haveria problemas para meu filho, porque el idioma más que todo... [...] Por exemplo, se eu estou aqui por três anos, cinco anos, tem muita gente que vem trabalhar aqui e vem com filhos, e filhos têm que ir a la escuela, e claro aqui escuela hay, mas tem esse problema do idioma, então quando a gente volta 
lá na Bolivia eles no quieren ni escribir, uno tem que presentar muitas coisas.

Quanto às expectativas em relação ao estudo, M2, mãe de 4 filhos disse: "ele vai na escolinha de adultos de noite, moça, para poder sair mais rápido do colégio para poder estudiar outra carreira, ele quiere ser alguna coisa, abogado, médico, como todo jovem aspira ser o melhor na vida". A maneira como os filhos responderam foi outra:

E3 - Eu já fiz um curso de programador de computador. Agora eu queria fazer a faculdade, mas eles não validam. Eles acham que vou embora, que não vou morar mais aqui.

E2 - Eu queria trabalhar com carros, fazer um curso de automotivo.

E4 - Eu de informática também.

No caso de E6, de 19 anos, que estava fora da escola, a ideia inicial era seguir no ramo da costura: "Pensei em trabalhar com algum coreano, pensei em fazer costura, ser piloteira.", afirmação que desagradou a mãe: "Eu falei para ela fazer outra coisa, mas não se anima para procurar". Nesse momento, a garota repetiu o que a máe vinha falando até então, o discurso sobre o medo de sair na rua, medo da escola, medo de um trabalho novo:

É que tenho um pouquinho de medo, o chefe ser um brasileiro ou coreano, são diferentes, tenho um pouquinho de medo. Eu não era assim, mas agora estou um pouco. Tenho um amigo que foi trabalhar em uma padaria e trabalha por dois, mas ganha por um. [...] Mas vai ser bom trabalhar fora, porque cansa, todos os dias a mesma coisa.

Finalmente, no caso de E5, que está finalizando o Ensino Médio, a perspectiva dela era de fato fazer uma faculdade em São Paulo - ao contrário dos muitos colegas que fazem os cursos técnicos ou ingressam diretamente no mercado de confecção. Primeiramente, disse que queria estudar hotelaria e turismo. Depois, pensou bem e mudou de ideia:

Meu sonho mesmo não é a USP, é a PUC. Tenho dois amigos que estudam lá e outros na USP. Eles foram voluntários da Anistia agora e trabalharam no CAMI, estudam relaçóes internacionais. Na verdade eu também queria estudar relaçóes internacionais.

Algumas conclusões

Neste estudo, buscamos entender como está sendo realizado o direito humano à educação para os e as imigrantes da Bolívia que vivem em São Paulo, e um 
primeiro passo é certamente tirar o tema da invisibilidade. Pouco sabemos sobre os bolivianos(as) que estão nas escolas. São pouco notados, pouco percebidos, desconhecidos. Consequentemente, nas políticas públicas não há ações focalizadas que considerem suas especificidades em nenhuma esfera (municipal, estadual ou federal), nível ou modalidade de ensino.

A universalização do direito à educação é percorrida por diversas tensões. É fato que a educação está disponivel, no sentido de que há escolas e há legislação que permite que a matrícula seja efetuada seja qual for o status da pessoa no País. Porém, a distância entre o que está garantido legalmente e o que se manifesta no cotidiano é um desafio em todos os campos dos Direitos Humanos, e, em nosso estudo, isso não foi diferente.

$\mathrm{O}$ acesso à educação é um primeiro fator que póe em xeque seu princípio de universalidade, na medida em que há barreiras aos imigrantes. Para aqueles em situaçáo irregular no País, ainda que a lei garanta esse direito, a falta de documentos é um entrave para entrar em cursos ou escolas, para mudar de escola (quando não facilitam o histórico escolar) e mesmo para sair (com a não emissão do certificado de conclusão de curso). Especialmente no caso dos que estão sem documentos, a burocracia e a falta de informaçôes sobre os direitos educativos são os muros que parecem mais evidentes.

Ultrapassando essa primeira fronteira e uma vez dentro da escola, o olhar sobre a aceitabilidade dessa educação trouxe elementos importantes que caracterizam um ambiente que pouco promove a aprendizagem e desafia a promoção dos direitos humanos.

De um lado, meninos e meninas sem nome, chamados de "Bolívia" pelos colegas e cuja voz é raramente ouvida pelos professores, foram descritos como calados, retraídos, silenciosos, falam pouco, participam pouco. E o que diz esse silêncio? Medo? Indiferença? Respeito à instituição escolar e reverência ao/à professor/a?

De outro lado, colegas, professores, funcionários da escola, que sabem muito pouco sobre eles e elas. Num primeiro momento, essa presença parece despertar uma reação ambígua: parecem estar perto e longe ao mesmo tempo, mas ainda são estranhos, em todo caso. E, se causam estranhamento, diz Mafesolli (2001), é porque já são parte.

Isso, já dizia Sayad (1998), ocorre quando os nacionais passam a vê-los(as) ali, ao lado, reivindicando qualquer coisa para além de servir como mão de obra num setor que os brasileiros(as) estariam muito pouco dispostos a ocupar. Aos poucos, dividirão o mesmo espaço, em nosso caso a mesma escola, a mesma rua, o mesmo posto de saúde. Nesses (des)encontros, escutamos discursos como "estão roubando nossos trabalhos", "por que não voltam para a Bolivia?"

Muitos reproduzem dentro da escola a relação conflituosa que estabeleceram no bairro - xingamentos, provocações, episódios de violência. A discriminação 
relatada nas entrevistas evidencia uma relação tensa, com os professores sem saber o que fazer, com poucos elementos para intervir.

No que tange à adaptabilidade desse direito, como é possível considerar as especificidades de alunos e alunas que nem sequer são notados? Nesse ponto, o idioma é uma questáo de partida a ser pensada, pois se configura como um impeditivo: é preciso primeiro "acostumar-se com o português" e só depois buscar a escola. Não seria razoável pensar em aulas de reforço, já que estes e estas estudantes não estão em pé de igualdade com os demais?

Por outro lado, existe a questão do idioma nativo, que lugar ocupará? Deve ser esquecido? Esse "esquecimento", nos relatos das entrevistas, é um traço que os identifica como bolivianos(as), e, frente ao cenário de discriminação, melhor escondê-lo.

Um dos temas contemporâneos das grandes cidades é o de como compartilhar o espaço. Os imigrantes, nesse contexto de renovados deslocamentos entre países, passam a viver ali ao lado, como diz Bauman (2008, p. 35), sem "terem sido convidados". Ao olhar para essa relação em diversos lugares do mundo, o autor constatou que "os estrangeiros tendem a parecer mais amedrontadores quanto mais distantes, desconhecidos e incompreensíveis os vemos". Em nosso estudo, exceto para grupos muito restritos, percebemos um diálogo ainda pequeno, tímido e insuficiente. A convivência nos espaços públicos é limitada, as fronteiras são reais.

Quebrar essa lógica, invertendo a dinâmica e provocando o reconhecimento, é um dos desafios que encontramos. Mas qual a possibilidade de uma experiência compartilhada, se não se compartilha o espaço de vivência? Uma experiência que vá além de uma convivência ali, lado a lado, mas numa real combinação das diferenças numa unidade de determinada vida coletiva, como indaga Touraine (1998)? A escola pública é um dos únicos e poucos espaços compartilhados, é ali que algumas barreiras deveriam ser derrubadas.

Diante da experiência violenta que seu filho viveu dentro de uma escola e também pelas travas causadas pelo idioma, uma das mães propôs a "escola separada". Seria uma escola só para bolivianos e bolivianas, revelando, assim, os dilemas em torno da aceitabilidade (qualidade) da escola. A ideia, contou ela, teria sido levantada numa conversa com outras mães - tanto bolivianas como brasileiras -, estas porque achavam que eram os imigrantes que estavam atrapalhando. Seria, assim, uma proposta definitiva para a resolução de conflitos?

A nosso ver e numa perspectiva de Direitos Humanos, a ideia da segregaçáo deveria ser rejeitada. Lembramos que o grande desafio contemporâneo é não aceitar os isolamentos e as segregaçóes - por idade, geraçóes, sexo ou sexualidade, raça, etnia, religião, classe ou grupo de status social ou profissional. Mais do que nunca, é importante criticar os guetos, os enclaves fortificados, o "não fale com estranhos" (Schilling, 2008). 
Para finalizar, voltemos ao início, quando situamos esta pesquisa como parte dos debates sobre os desafios da universalizaçâo de direitos em sociedades desiguais e discriminatórias. A busca pela realização plena do direito humano à educação inclui, como dissemos, para além do acesso em si, a preocupação com o modo como se dá a permanência no sistema. Sua realização acontece se as dimensões da disponibilidade, da acessibilidade, da aceitabilidade e da adaptabilidade forem protegidas, realizadas e promovidas de maneira conjunta.

O caminho para a realização plena do direito à educação para os e as imigrantes da Bolívia passa por todos esses desafios e, a nosso ver, pode começar por um processo de escuta e amplificação de suas vozes.

\section{Referências bibliográficas}

BAUMAN, Z. Confianza y temor en la ciudad; vivir con extranjeros. Barcelona: Arcadia, 2005.

BONASSI, M. Canta, América sem fronteiras! Imigrantes latino-americanos no Brasil. São Paulo: Loyola, 2000.

BRASIL. Lei Federal n. 8069/90 - de 13 de julho de 1990. Dispóe sobre o Estatuto da Criança e do Adolescente e dá outras providências.

BRASIL. Lei 6815. Lei do estrangeiro. Artigo 48.

BRASIL. Constituição Federal. 1988.

Convençáo Internacional sobre a Proteçáo de Todos os Trabalhadores Migrantes e Seus Familiares. Artigo 30.

CYMBALISTA, R; ROLNIK, I. Comunidade boliviana em Sáo Paulo: definindo padróes de territorialidade. Cadernos Metrópole. São Paulo, v. 17, pp. 119-133, 2007.

ESTADO. Conselho Estadual de Educação. Deliberação 16/1997.

ESTADO. Conselho Estadual de Educação. No 633/2008.

ESTADO. Secretaria da Educação do Estado de São Paulo. Resoluçấo 9. 1994.

ESTADO. Secretaria da Educação do Estado de São Paulo. Resolução 10. 1995.

FERNANDES, F. Folclore e mudança social na cidade de São Paulo. Sáo Paulo: Anhembi, 1961.

IANNI, O. Capitalismo, violência e terrorismo. Rio de Janeiro: Civilização Brasileira, 2004.

INTERNATIONAL ORGANIZATION FOR MIGRATION (IOM). World Migration Report 2008: Managing Labour Mobility in the Evolving Global Economy. Genebra: IOM, 2008.

LAFER, C. A reconstrução dos direitos humanos: um diálogo com o pensamento de Hannah Arendt. São Paulo: Companhia das Letras, 1988. 
LOS DERECHOS de los no ciudadanos. Alto Comisionado de las Naciones Unidas para los Derechos Humanos. Nova Iorque; Genebra, 2006.

MAFFESOLI, M. Sobre o nomadismo - vagabundagens pós-modernas. Rio de Janeiro - Sáo Paulo: Record, 2001.

MARTINS, J. de S. Por uma pedagogia dos inocentes. Tempo Social, Rev. Sociologia USP. S. Paulo, v. 13, n. 2 , p. 21-30, nov. 2001.

MUNICÍPIO. Conselho Municipal de Educação. Parecer 17/2004.

MUNOOZ, V. The right to education of migrants, refugees and asylum-seekers. Relatório apresentado ao Conselho de Direitos Humanos da ONU. Genebra; New York: UN General Assembly, 2010. (Identificador: A/HRC/14/25).

Observação Geral n 13 sobre o Direito à Educação. Comitê de Direitos Econômicos, Sociais e Culturais (DESC) das Naçóes Unidas, 1999.

OFICINA DEL ALTO COMISIONADO DE LAS NACIONES UNIDAS PARA LOS DERECHOS HUMANOS. Los derechos de los no ciudadanos. Nova Iorque; Genebra: Naciones Unidas, 2006.

Relatório final da Comissão Parlamentar de Inquérito para apurar a exploração do trabalho análogo ao escravo na cidade de São Paulo. (Identificador: 0024/2005). Câmara Municipal de São Paulo, 2006.

SANTOS JÚNIOR, B. Os direitos humanos e alguns aspectos da situação do estrangeiro. Revista do Advogado, ano 1, n. 3, p. 50-53, 1980.

SÃO PAULO (Município). Relatório final da Comissão Parlamentar de Inquérito para apurar a exploração de trabalho análogo ao de escravo. Sáo Paulo: Câmara Municipal, 2006.

SAYAD, A. A imigração. São Paulo: Edusp, 1998.

SCHILLING, F. O direito à educação, um longo caminho. In: BITTAR, E. C. B. (Org.). Educação e metodologia para os direitos humanos. Sáo Paulo: Quartier Latin, 2008. p. 273-283.

SILVA, S. A. da. Bolivianos em São Paulo: entre o sonho e a realidade. Dossiê Migraçóes. São Paulo, v. 20, n. 57, p. 157-170, maio/ago., 2006.

SILVA, S. A. da. Os imigrantes e os direitos humanos no Brasil. In: SERVIÇO PASTORAL DO MIGRANTE (org). Travessia da Desordem Global - Fórum Social das Migraçóes. São Paulo: Paulinas, 2005.

SILVA, S. A. da. Bolivianos: a presença da cultura andina. Sáo Paulo: Companhia Editora Nacional, 2005.

SILVA, S. A. da. Costurando sonhos: trajetória de um grupo de imigrantes bolivianos em São Paulo. São Paulo: Paulinas, 1997.

SILVA, S. A. da. Virgem, Mãe, Terra. Festas e tradiçóes bolivianas na metrópole. São Paulo: Hucitec - Fapesp, 2003. 
SOUSA SANTOS, B. A gramática do tempo - para uma nova cultura política. São Paulo: Cortez, 2006.

TOMASEVSKI, K. Human rights obligations in education: The 4-A Scheme. Wolf, Nijmegen, 2006.

TOURAINE, A. Poderemos viver juntos? Iguais e diferentes. Petrópolis: Vozes, 1998.

Recebido em 15 de julho de 2011 e aprovado em 23 de setembro de 2011. 